\title{
Genetic diversity among eight Dendrolimus species in Eurasia (Lepidoptera: Lasiocampidae) inferred from mitochondrial COI and COII, and nuclear ITS2 markers
}

Alexander Kononov ${ }^{1 *}$, Kirill Ustyantsev ${ }^{1}$, Baode Wang ${ }^{2}$, Victor C. Mastro² ${ }^{2}$ Victor Fet ${ }^{3}$, Alexander Blinov ${ }^{1}$ and Yuri Baranchikov ${ }^{4}$

From The International Conference on Bioinformatics of Genome Regulation and StructurelSystems Biology (BGRSISB-2016) Novosibirsk, Russia. 29 August-2 September 2016

\begin{abstract}
Background: Moths of genus Dendrolimus (Lepidoptera: Lasiocampidae) are among the major pests of coniferous forests worldwide. Taxonomy and nomenclature of this genus are not entirely established, and there are many species with a controversial taxonomic position. We present a comparative evolutionary analysis of the most economically important Dendrolimus species in Eurasia.
\end{abstract}

Results: Our analysis was based on the nucleotide sequences of COI and COII mitochondrial genes and ITS2 spacer of nuclear ribosomal genes. All known sequences were extracted from GenBank. Additional 112 new sequences were identified for 28 specimens of D. sibiricus, D. pini, and D. superans from five regions of Siberia and the Russian Far East to be able to compare the disparate data from all previous studies. In total, 528 sequences were used in phylogenetic analysis. Two clusters of closely related species in Dendrolimus were found. The first cluster includes $D$. pini, D. sibiricus, and D. superans; and the second, D. spectabilis, D. punctatus, and D. tabulaeformis. Species D. houi and D. kikuchii appear to be the most basal in the genus.

Conclusion: Genetic difference among the second cluster species is very low in contrast to the first cluster species. Phylogenetic position D. tabulaeformis as a subspecies was supported. It was found that D. sibiricus recently separated from D. superans. Integration of D. sibiricus mitochondrial DNA sequences and the spread of this species to the west of Eurasia have been established as the cause of the unjustified allocation of a new species: D. kilmez. Our study further clarifies taxonomic problems in the genus and gives more complete information on the genetic structure of $D$. pini, $D$. sibiricus, and D. superans.

Keywords: Dendrolimus, Phylogeny, Pests, Interspecific hybridization, Divergence

\footnotetext{
*Correspondence: kononov.nov@mail.ru

${ }^{1}$ Institute of Cytology and Genetics, the Siberian Branch of the Russian

Academy of Science, 10 Prospekt Lavrentyeva, Novosibirsk 630090, Russia

Full list of author information is available at the end of the article
} 


\section{Background}

Moths of the genus Dendrolimus (Lepidoptera: Lasiocampidae) are among the main pests of coniferous forests worldwide [1]. The majority of experts distinguish about 30 species in the genus, but only six are widespread in Eurasia [2]. These pests have vast geographic ranges and cause serious damage to forestry in many countries. Examples of harmful Dendrolimus species are D. pini (Linnaeus [3]), D. sibiricus (Tschetverikov [4]) and D. punctatus (Walker [5]). They are thought to be the most dangerous and widespread species of this genus [2]. D. punctatus is found in the south-eastern part of Eurasia. Outbreaks of this species occur approximately over one million ha each year in China [6]. D. pini is widely distributed across Europe, Central Asia, and North Africa [7] and its outbreaks could also cover vast areas. For example, D. pini destroyed about 233,000 ha of forest in Poland from 1946 to 1995 . Outbreaks of this pest were also registered in Germany and Russia [8].

The Siberian moth, D. sibiricus, is one of the most dangerous pests of coniferous forests in Northern Asia. D. sibiricus range occupy territories from the coasts of the Okhotsk and the Japanese Seas to the Ural Mountains [9]. The pest was detected in western Russia and it can be identified even in Central Europe [2, 10, 11]. The European and Mediterranean Plant Protection Organization (EPPO) included D. sibiricus in its A2 list of pests recommended for quarantine in member countries [12]. Outbreaks of $D$. sibiricus can cause a huge damage to ecosystems over large territories [13]. At least nine outbreaks were reported in the Central Siberia where they covered an area around 10 million hectares during the last century [14].

Two other species, D. houi (Lajonquière [15]) and $D$. kikuchii (Matsumura [16]), are most frequently encountered in eastern Asia and are economically important pests of coniferous forests in South China [17]. During outbreak years of $D$. houi from thousands to millions of hectares of forests can be killed [18]. The second species, D. kikuchii, is broadly distributed across Southern China and causes serious damage to trees in provinces of this territory. In the Simao Prefecture, the swarming of its adults overlap with the seasonal flight periods of the broadly sympatric species, D. houi [19].

Taxonomy and nomenclature of Dendrolimus are not entirely established, and there are many species with a controversial taxonomic position. D. punctatus, D. tabulaeformis (Tsai \& Liu [20]) and D. spectabilis (Butler [21]) have an uncertain species status. D. tabulaeformis and $D$. spectabilis had been considered as a subspecies of D. punctatus [22]. However, all three species were treated as different in other studies [23]. Taxonomic relationship of $D$. sibiricus and D. superans (Butler [21]) is also problematic. According to the consensus opinion, D. sibiricus and D. superans are separate species, although some researchers consider that there is a single species $D$. superans with two subspecies: Dendrolimus superans sibiricus Tschetverikov and Dendrolimus superans albolineatus Butler [9].

In 2008, a new species, Dendrolimus kilmez, was described from Kilmez, Central Russia [2]. The new species was morphologically similar to $D$. pini, and had identical ITS2 nuclear DNA sequences with it, but was very different from $D$. pini according to a 3' COI mitochondrial DNA marker.

Genetic diversity is an important indicator of the ability of a species or individual populations to adapt to the environment. Species or populations with greater genetic diversity are better adapted to changing environmental conditions [24, 25]. Therefore, they are more likely to expand their habitats and geographic ranges. Studies of genetic variation provide information on the origin and divergence of species and explain their geographical distribution. This information can also help to understand the quarantine measures which should be implemented in cases of pest species $[26,27]$. New, genetically homogenous populations can be formed by fast migration to the territories, which are sufficiently distant from the source range [28]. The degree of genetic diversity of the newly formed populations can reach the genetic diversity of source populations as the range expands and population grows [26].

In this paper we studied the genetic structure of populations of eight Dendrolimus species widespread in Eurasia. A few original studies exist that address genetic diversity and phylogeny only of individual species or groups of closely related species of Dendrolimus [2, 29, 30]. These studies provided information only about populations from western (Europe) and eastern (China) parts of Eurasia; however, a large portion of $D$. sibiricus and $D$. pini ranges lies in Siberia [12, 31]. In addition, in each work different genetic markers were used. This fact complicates the comparison and synthesis of the results of performed researches. The present study used all the information about the genetic diversity of Dendrolimus known to date. Specimens from populations of central part of Eurasia were collected for a more complete understanding of the genetic structure of the genus, bringing together geographically separated areas of previous research. We used all the genetic markers previously used in the studies of the genus Dendrolimus. That made possible to compare the disparate data from previous studies. We provide the most up-todate information on the genetic differentiation of populations of the eight the most important Dendrolimus species in Eurasia including nearest islands. Species which were investigated in the current work represent the majority of the Dendrolimus species across this region. Our study 
further clarifies taxonomic problems in the genus and gives more complete information on the genetic structure of $D$. pini, D. sibiricus, and D. superans.

\section{Methods \\ Collection of material, isolation of genomic DNA, PCR amplification and sequencing}

Larvae and moths of D. pini, D. superans, and D. sibiricus were collected in the natural populations across Asian Russia (Siberia, the Russian Far East, and the Sakhalin Island). Localities, number of collected specimens and Genbank accession numbers are listed in Additional file 1 . No special permits were required for the described field studies, the localities were not privately owned, and the field studies did not involve endangered or protected species.

Genomic DNA was extracted from insect tissues using the DNeasy Blood \& Tissue Kit (QIAGEN, Valencia, CA) in accordance with the manufacturer's protocol.

Partial mtDNA sequences of COI and COII genes, about 1400 and 600 bp long, correspondingly, and ITS2 sequences $(400 \mathrm{bp})$ were amplified by PCR using specific primer pairs listed in Table 1. For details of the extraction and PCR amplification, PCR purification and sequencing, see Vavilova et al. [32]. The insertion sequences were sequenced on an automated sequencer ABI PrISM 3100 Avant Genetic Analyzer (Applied Biosystems, USA) with a Big Dye terminator sequencing kit (Applied Biosystems, USA) at the SB RAS Genomics Core Facility (Novosibirsk, Russia, http://sequest.niboch.nsc.ru).

\section{Database screening}

DNA sequences of the COI, COII and ITS2 genes of Dendrolimus species were extracted from Genbank database of the National Institutes of Health (NCBI), USA, using "(Dendrolimus[Organism]) AND (COI OR CO1)", "(Dendrolimus[Organism]) AND (COII OR CO2)" and "(Dendrolimus[Organism]) AND ITS2" as search queries. It should be noted that the European population represented only sequences from Genbank. However,

Table 1 Primers used for PCR amplification of the fragments of nuclear and mitochondrial genes

\begin{tabular}{|c|c|c|c|}
\hline $\begin{array}{l}\text { DNA } \\
\text { fragment }\end{array}$ & Primers & Sequence & Source \\
\hline \multirow{2}{*}{$\begin{array}{l}3^{\prime} \text { end of } \\
\text { col gene }\end{array}$} & M5 & 5'- CAACATTATITTGATITITTGG-3' & [2] \\
\hline & M3 & 5'- CCAATGCACTAATCTGCCATATTA-3' & {$[2]$} \\
\hline \multirow{2}{*}{$\begin{array}{l}5^{\prime} \text { end of } \\
\text { COl gene }\end{array}$} & 911 & 5'-TTTCTACAAATCATAAAGATATTGG-3' & [44] \\
\hline & 912 & 5'-TAAACTTCAGGGTGACCAAAAATCA-3' & {$[44]$} \\
\hline \multirow{2}{*}{$\begin{array}{l}\text { Portion of } \\
\text { coll gene }\end{array}$} & $\mathrm{C} 2 \mathrm{~N}$ & 5'- CCACAAATTTCTGAACATTGACCA -3' & [45] \\
\hline & C2J & 5'- AGAGCTTCTCCTITAATAGAACA -3' & [45] \\
\hline \multirow[t]{2}{*}{ ITS2 } & ITS2A & 5'- TGTGAACTGCAGGACACAT -3' & [2] \\
\hline & ITS2B & 5'- TATGCTTAAATTGAGGGGGT -3' & [2] \\
\hline
\end{tabular}

this sequences participated in all comparative analyzes, together with all experimentally obtained samples. Outgroup species for phylogenetic analysis of ITS2 and COII sequences were selected from Genbank using BLASTn (NCBI). Sequences of Zygaena tamara and Zygaena seitzi were chosen for ITS2. Sequences of Odontopus sanguinolens and Odontopus nigricomis were chosen for COII. For uniformity to analyses of the mitochondrial markers COI the regions from complete mitochondrial genomes of Biston panterinaria and Phthonandria atrilineata were used as outgroup [33].

\section{Sequence analysis}

Multiple sequence alignment was performed by MUSCLE algorithm in UGENE 1.12 [34]. Analysis of phylogeny by maximum-likelihood (ML) was carried out in PhyML 3.0 program with default settings and with the aLRT as a topology estimation method [35].

\section{Results and Discussion}

Database screening, collection of new samples, and sequencing

In order to assess genetic structure of Dendrolimus populations we aimed to retrieve mitochondrial COI and COII sequences, and ITS2 nuclear sequences for eight Dendrolimus species currently available in GenBank (NCBI). To integrate disparate data we used seven specimens of $D$. pini from two natural populations of Altai and Krasnoyarsk regions; 17 samples of D. sibiricus from three populations of Khakassia, Krasnoyarsk, and Sakhalin regions; and four specimens of D. superans from the Far East of Russia (Fig. 1). Total DNA was extracted from each specimen and amplified by PCR with primers specific for COI (5' and $3^{\prime}$ ends) and COII mitochondrial genes, and for ITS2 nuclear ribosomal DNA gene. Totally, 112 DNA fragments were isolated and sequenced.

The source and localities for all obtained sequences are shown in Table 2 and the total number of COI, COII, and ITS sequences used in the present work are summarized in Table 3 . The total length of the DNA fragments was 590, 728, 538 and 504 bp for $5^{\prime}$ COI, 3' COI, COII, and ITS2, correspondingly.

\section{Phylogeny of the Dendrolimus species}

ML phylogenetic trees were reconstructed based on multiple sequence alignments of four different DNA sequences: ITS2, 5' COI, 3' COI and COII of Dendrolimus species (Figs. 2, 3, 4 and 5). Two clusters of closely related species were distinguished on the all phylogenetic trees. The first cluster (SPT, by the first letter in species' name) is formed by $D$. spectabilis, D. punctatus, and $D$. tabulaeformis. D. spectabilis is a quite clearly separated species in the SPT cluster in contrast to D. punctatus and $D$. tabulaeformis which form a closely related group. 


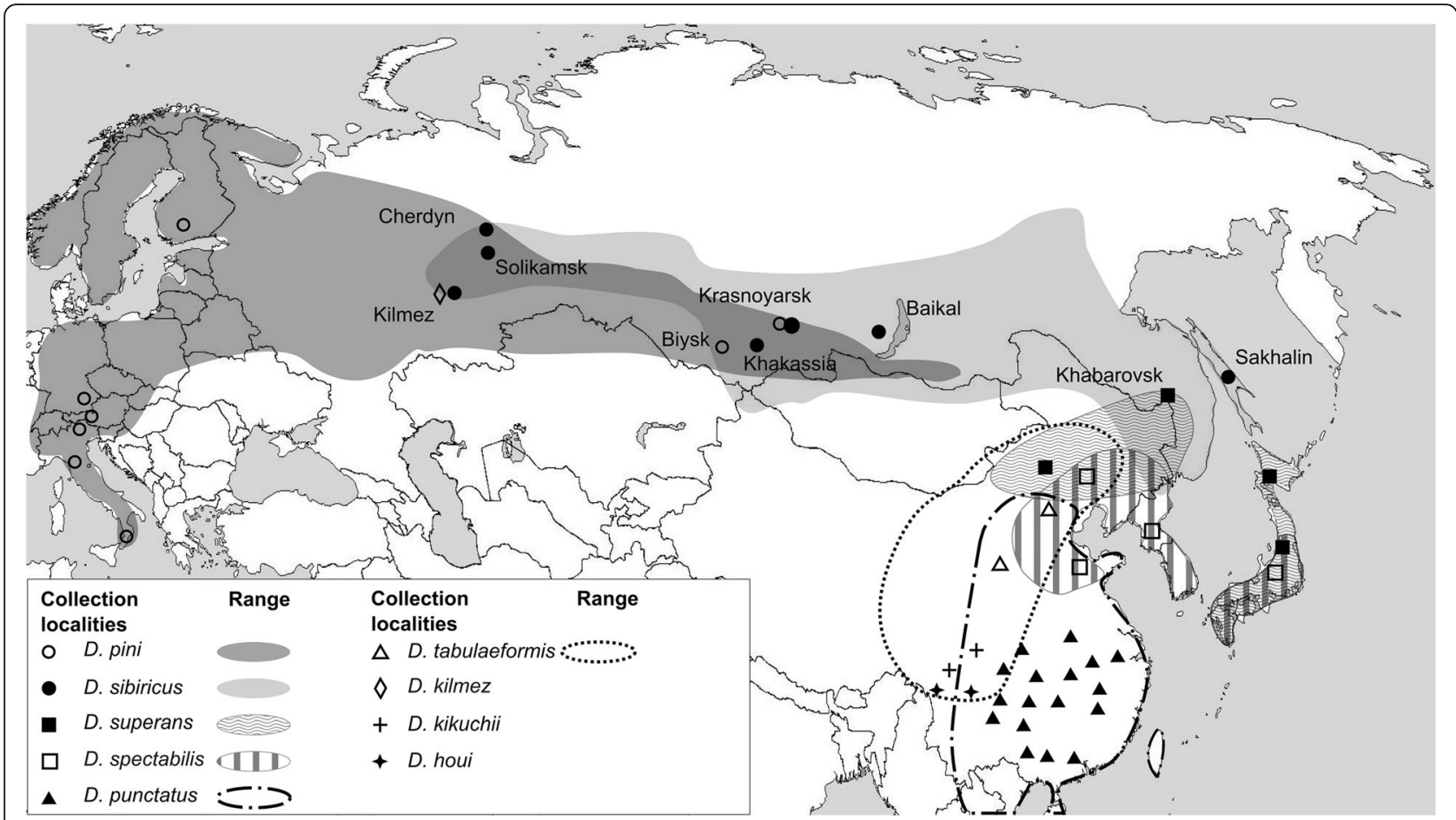

Fig. 1 Collection localities and ranges of Dendrolimus species analyzed in this work from Europe and Asia. Approximate geographic ranges are indicated by color/texture or circled with a dotted line (http://www.cabi.org/dmpp, CABI 2013) [46]. The overlapping ranges of different species are shown in overlapping textures or shades. Collection localities labeled the settlement name but not the country name signed on the map

The second cluster (PSS, by the first letter in species' name) is formed by three species: $D$. pini, D. sibiricus, and D. superans. D. superans is more closely related to D. sibiricus than to D. pini. Two species, D. kikuchii and D. houi, are the most distant from all other Dendrolimus species, and the most basal species in the genus.

\section{Phylogenetic relationships and phylogeography of species in the SPT cluster}

D. spectabilis, D. tabulaeformis and D. punctatus species can be isolated in the separate cluster based on the all analyzed markers. According to mitochondrial sequences $D$. spectabilis are clearly allocated into the group which is close to $D$. tabulaeformis and D. punctatus but which evolved independently of them (Figs. 3, 4 and 5). In contrast, D. tabulaeformis is not distinguishable from the D. punctatus on the all COI and ITS2 phylogenetic trees supporting its subspecies status [33]. In concordance with the ITS2 tree, SPT cluster looks more homogeneous due to the lower resolution of nuclear markers (Fig. 2). A similar pattern of relationships between species of the SPT cluster has been shown by a series of other molecular barcoding methods [36]. Furthermore, recent studies of mitochondrial genomes of these species provide an analogous results [33].

Species of the SPT cluster have highly overlapping geographic ranges (Fig. 1). Therefore, this situation can be explained by absence of geographical isolation among these species, which could lead to the constant gene flow even between relatively distant populations of different species; consequently, a clearly separated, independent population could not be formed. A high degree of genetic variability is a common feature of populations with a continuous range (absence of geographical isolation), high abundance, and an ability to disperse over large distances (typical for flying insects). All this allows for gene flow between even relatively distant groups that results in genetic heterogeneity of individual populations [26, 37, 38]. This situation is applicable to populations of $D$. tabulaeformis, and $D$. punctatus, where a high degree of genetic variability is confirmed by phylogenetic analysis of mitochondrial and nuclear DNA sequences (Figs. 2, 3, 4 and 5).

\section{Phylogenetic relationships and phylogeography of species in the PSS cluster \\ $D$. sibiricus and $D$. superans}

According to the recent review [2], D. sibiricus and D. superans are currently considered separate species. The same was declared by EPPO at 2005, based on an unidentified international opinion [12]. However, other reviews considered $D$. sibiricus to be a subspecies of $D$. superans $[9,39]$.

Our results demonstrate that $D$. sibiricus and $D$. superans are clearly distinguished from each other based on the 
Table 2 Collection localities, sources, and the sequence types of Dendrolimus species included in this study

\begin{tabular}{|c|c|c|c|}
\hline Species & Locality & Sequence type & Source \\
\hline \multirow[t]{6}{*}{ D. pini } & Finland & $\mathrm{COI} 3^{\prime}$, ITS2 & {$[2]$} \\
\hline & Germany & $\mathrm{COI} 5^{\prime}$ & GU654860, JF415336-JF415341 \\
\hline & Italy & $\mathrm{COI} 5^{\prime}$ & GU688542, HM914063, JF860056 \\
\hline & Biysk, Russia & COI 5', COI 3', ITS2, COII & the present work \\
\hline & Krasnoyarsk, Russia & COI 5', COI 3', ITS2, COII & the present work \\
\hline & Kilmez, Russia & $\mathrm{COI} 3^{\prime}$, ITS 2 & {$[2]$} \\
\hline \multirow[t]{7}{*}{ D. sibiricus } & Cherdyn, Russia & $\mathrm{COI} 3^{\prime}$, ITS 2 & {$[2]$} \\
\hline & Kilmez, Russia & $\mathrm{COI} 3^{\prime}$, ITS 2 & {$[2]$} \\
\hline & Baikal, Russia & $\mathrm{COI} 3^{\prime}$, ITS 2 & {$[2]$} \\
\hline & Solikamsk, Russia & COI 3', ITS 2 & {$[2]$} \\
\hline & Krasnoyarsk, Russia & $\mathrm{COl} 5^{\prime}, \mathrm{COI} 3^{\prime}, \mathrm{ITS} 2, \mathrm{COII}$ & the present work \\
\hline & Khakassia, Russia & COI 5', COI 3', ITS2, COII & the present work \\
\hline & Sakhalin, Russia & $\mathrm{COI} 5^{\prime}, \mathrm{COI} 3^{\prime}, \mathrm{ITS} 2, \mathrm{COII}$ & the present work \\
\hline \multirow[t]{3}{*}{ D. superans } & Japan & $\mathrm{COI} 3^{\prime}$, ITS 2 & {$[2]$} \\
\hline & China & COI 5', ITS 2 & {$[29,30]$} \\
\hline & Khabarovsk, Russia & COI 5', COI 3', ITS2, COII & the present work \\
\hline \multirow[t]{3}{*}{ D. spectabilis } & Japan & ITS 2 & {$[2]$} \\
\hline & China & $\mathrm{COI} 5^{\prime}, \mathrm{COI} 3^{\prime}, \mathrm{ITS} 2, \mathrm{COII}$ & {$[29,30,33]$} \\
\hline & South Korea & $\mathrm{COI} 5^{\prime}$ & KC135936; JN087390 \\
\hline D. punctatus & China & COI 5', COI 3', ITS2, COII & {$[29,30,33]$} \\
\hline D. tabulaeformis & China & COI 5', COI 3', ITS2, COII & {$[29,30,26]$} \\
\hline D. houi & China & $\mathrm{COI} 5^{\prime}, \mathrm{COI} 3^{\prime}$, ITS 2, COII & {$[29,30]$} \\
\hline D. kikuchii & China & COI 5', ITS 2, COII & {$[29,30]$} \\
\hline
\end{tabular}

phylogenetic analysis of ITS2 sequences (Fig. 2). This situation confirms the first viewpoint on $D$. sibiricus as on the separate species. At the same time, continental populations of these two species are identical according to the mitochondrial markers (Figs. 3, 4 and 5). This result supports $D$. sibiricus as a subspecies. Furthermore, sequences of both species from island populations formed a separate clearly distinguishable group according with the 3' COI tree (Fig. 4). Continental populations of D. superans are more

Table 3 Number and types of Dendrolimus sequences analyzed in this work

\begin{tabular}{llllll}
\hline Species & $5^{\prime}$ COI & $3^{\prime}$ COI & ITS2 & COII & Total \\
\hline D. pini & 17 & 15 & 15 & 7 & 54 \\
D. sibiricus & 17 & 28 & 30 & 17 & 92 \\
D. superans & 18 & 14 & 23 & 4 & 59 \\
D. spectabilis & 25 & 2 & 14 & 2 & 43 \\
D. punctatus & 91 & 4 & 25 & 4 & 124 \\
D. tabulaeformis & 43 & 2 & 27 & 2 & 74 \\
D. kikuchii & 32 & 0 & 16 & 4 & 52 \\
D. houi & 14 & 2 & 10 & 4 & 30 \\
& & & & & 528 \\
\hline
\end{tabular}

divergent from the Japanese populations of the same species than from continental populations of $D$. sibiricus. Consequently, divergence between continental and island populations within a species exceeds interspecies divergence.

It is clear that populations of $D$. sibiricus and $D$. superans shared the nearest common ancestor with respect to other PSS species, as evidenced by ITS2 and COI phylogenies (Figs. 2, 3 and 4). Considering that current range of $D$. sibiricus exceeds the $D$. superans range and the $D$. sibiricus populations are now dispersed in Northeastern Asia, it can be suggested that isolation of $D$. sibiricus as a distinct, but closely related to D. superans species, is a matter of short time. Rozhkov [40] also considered $D$. sibiricus to be a relatively young and "progressive" species with unstable population dynamics.

Both nuclear and mitochondrial sequences of $D$. sibiricus populations are completely identical throughout the species range, except of the samples from Sakhalin Island. Such homogeneity can be explained by periodic pandemic outbreaks of $D$. sibiricus, which can cover up to 10 million hectares with intensive migrations throughout outbreak area and neighboring territories [14]. Based on the 5' COI, 3' COI and COII sequence analyses, there are at least two mitochondrial haplotypes of $D$. sibiricus 


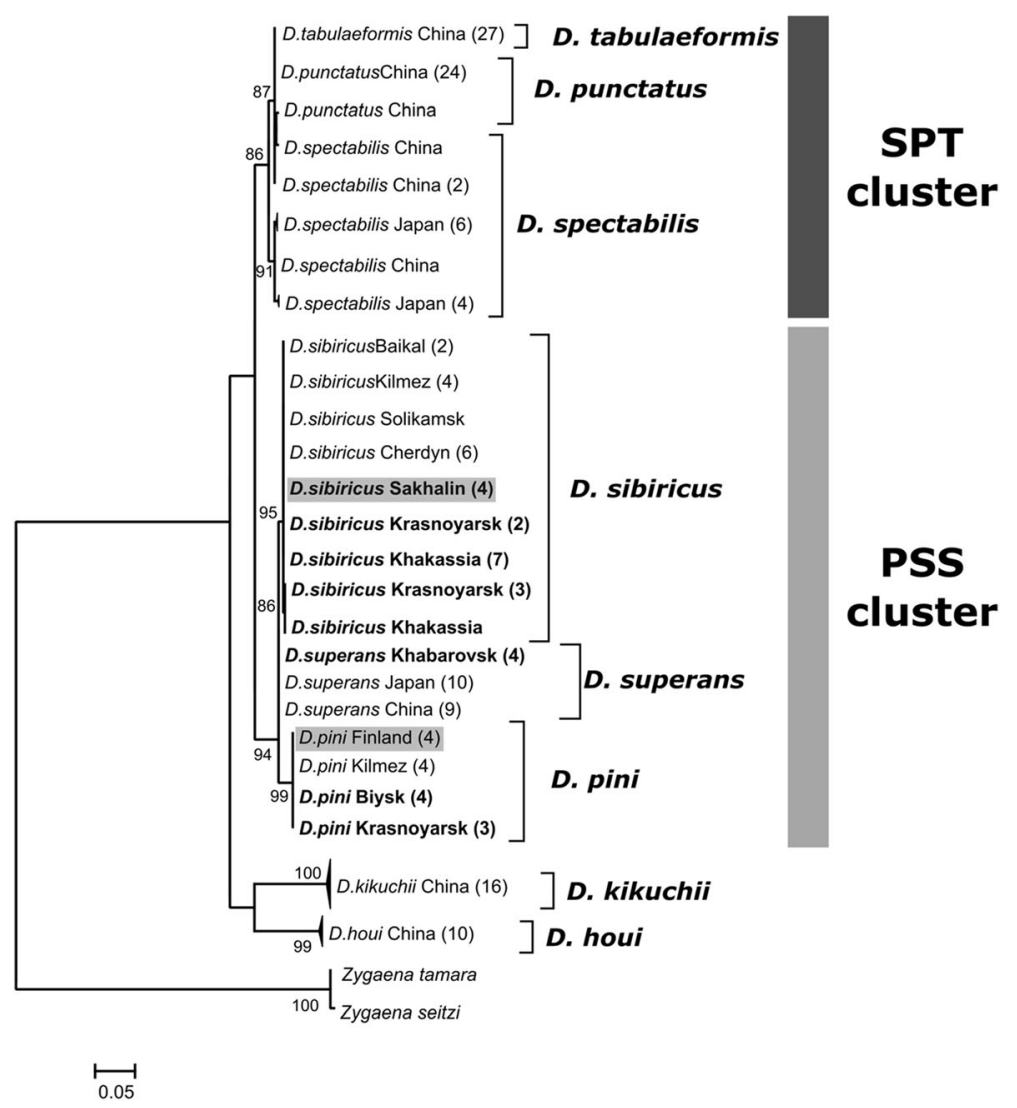

Fig. 2 Phylogeny of Dendrolimus based on ITS2 nuclear sequences. Names of the samples that were obtained in the present study are indicated in bold. SPT, cluster of closely related species: D. spectabilis, D. punctatus and D. tabulaeformis. PSS, cluster of closely related species: D. pini, D. sibiricus and D. superans. Specimens whose position was in disagreement with the accepted taxonomy are shown in gray. Sequences of the Zygaena genus were used as the outgroup. The coefficients near the tree nodes represent the statistical support for respective branches. The coefficients below 80 are not shown in the picture

in the Sakhalin Island. One of these haplotypes is identical to the continental variant, while another one is unique to Sakhalin.

Similar situation was observed for D. superans. Japanese populations of this species are represented by four unique mitochondrial haplotypes based on 3' COI tree (Fig. 4). Two of these haplotypes are similar to those of the continental populations of $D$. superans, and two others are similar to the unique D. sibiricus haplotype from Sakhalin.

Effect of geographic isolation on genetic diversity within populations of one or more closely related species has been shown repeatedly in various studies on both interspecific and intraspecific variability in insects [37, 41, 42]. A general pattern is seen in all described cases: gene flow is common between closely related species of insects with overlapping ranges or common plant hosts. Frequent gene flow results in the formation of genetically homogeneous populations of different morphotypes at the junction of the common ranges and habitats and, conversely, in an increase in interspecific divergence when moving away from them, like in SPT cluster. Isolated populations sever all contacts with source populations, and start forming genetically isolated groups, with at least one haplotype represented in the presence of a more rigorous barrier than isolation by distance (such as mountains or watersheds), but they are still morphologically identical to the source species [37]. A similar situation is observed in the case of the continental and island populations of D. superans and D. sibiricus.

\section{D. pini, D. sibiricus, and D. kilmez}

D. pini sequences formed the isolated branch in PSS cluster on the all analyzed trees. All studied $D$. pini from the populations located at large distances from each other showed no genetic variability in ITS2 (Fig. 2). There are differences in mitochondrial gene sequences both between distant populations and within the same population of D. pini (Fig. 3). D. pini populations from Finland were separated from all other populations of this species on the 3 'COI phylogenetic tree. They grouped together with the samples of $D$. sibiricus from mainland populations (Fig. 4). Thus, D. pini from Finland are identical to $D$. sibiricus according to mitochondrial markers, but identical to the other $D$. pini 


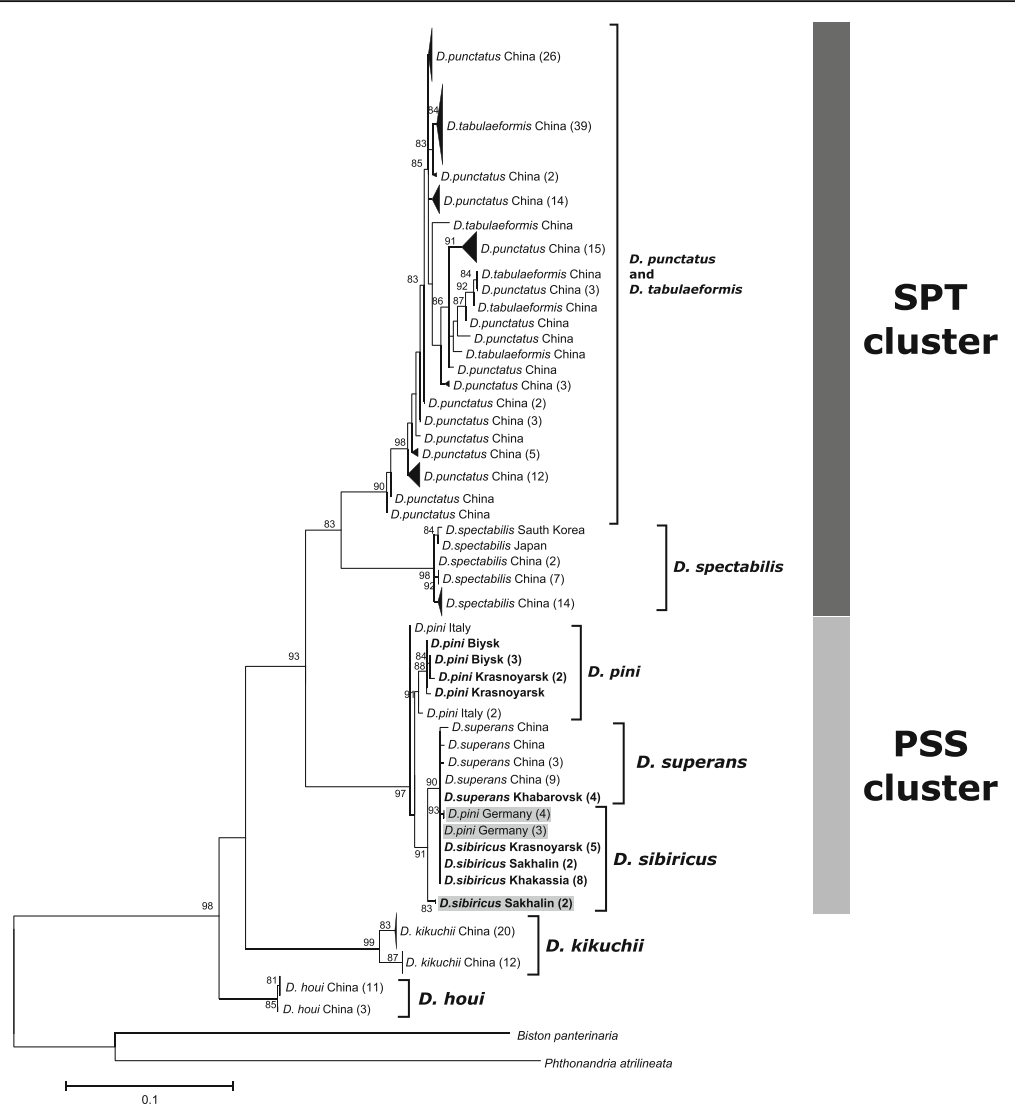

Fig. 3 Phylogeny of Dendrolimus based on $5^{\prime}$-end portion of COI gene. Specimens obtained in the present study are shown in bold. SPT, cluster of closely related species: D. spectabilis, D. punctatus and D. tabulaeformis. PSS, cluster of closely related species: D. pini, D. sibiricus and D. superans. Specimens whose position was in disagreement with the accepted taxonomy are shown in gray. Sequences of the Biston and Phthonandria genus were used as the outgroup. The coefficients near the tree nodes represent the statistical support for respective branches. The coefficients below 80 are not shown in the picture

specimens according to nuclear markers (Figs. 2 and 4). In addition, $D$. pini from Europe (Germany, Bavaria) were also identical to $D$. sibiricus according to the $5^{\prime}$ COI phylogeny (Fig. 3). Therefore, some European populations contain $D$. pini individuals with the mitochondrial marker sequences completely identical to $D$. sibiricus.

In 2008, a phylogenetic study of Dendrolimus was conducted [2]. In this work, populations of different Dendrolimus species from Japan, Russia (Kilmez and Solikamsk) and Finland were investigated. The four samples from Finland were identified as $D$. pini and the four samples from Kilmez (Russia), as a new species named D. kilmez. The new species was very similar to $D$. pini morphologically, but differed genetically from the Finnish populations of D. pini, based on the 3' COI sequence analysis [2]. Our phylogenetic analysis, in addition to the Finnish populations of $D$. pini, included specimens from Italy, Germany and Russia (Siberia). D. kilmez clustered together with D. pini specimens, which were added in the current work (Figs. 2 and 4). Therefore, according to both nuclear and mitochondrial markers, the $D$. kilmez individuals are members of the
D. pini species. In contrast, specimens of $D$. pini from Finland clustered together with $D$. sibiricus on the 3' COI phylogenetic tree (Fig. 4), but not with the other D. pini. However, according to the ITS2 phylogeny, D. pini from Finland clearly belong to $D$. pini (Fig. 2). This means that mitochondrial differences of the Finnish individuals differ from other $D$. pini caused the incorrect assignment of Kilmez individuals to a separate species. Eventually specimens named $D$. kilmez represents the typical $D$. pini and Finnish $D$. pini specimens differ from other $D$. pini on the mitochondrial level.

The presence of mitochondrial DNA sequences of $D$. sibiricus simultaneously with the nuclear DNA sequences of $D$. pini in the Finnish and Germany individuals can be explained by the possibility of cross-hybridization between D. sibiricus and D. pini. D. sibiricus and D. pini have overlapping ranges through nearly all south of Western and Eastern Siberia (Fig. 1). Their breeding seasons also overlap and their sex pheromones are very close. $D$. sibiricus can occure in the same habitats with $D$. pini (e.g., as it takes place in the Pinus sylvestris forests in the foothills of 


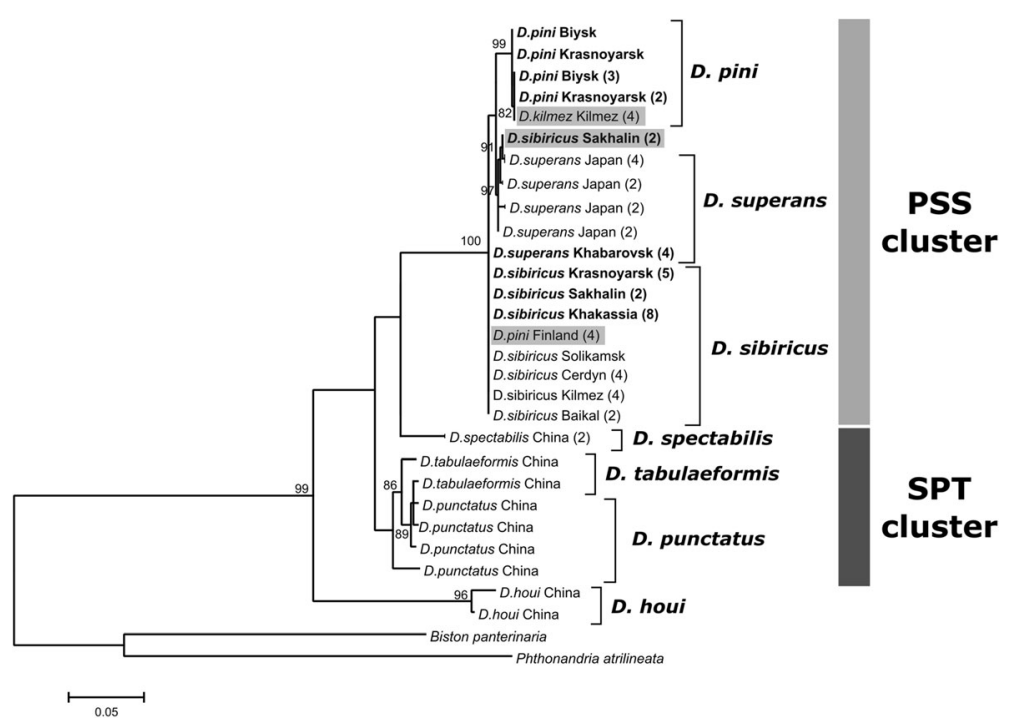

Fig. 4 Phylogeny of Dendrolimus based on $3^{\prime}$-end portion of COI gene. Specimens obtained in the present study are shown in bold. SPT, cluster of closely related species: D. spectabilis, D. punctatus and D. tabulaeformis. PSS, cluster of closely related species: D. pini, D. sibiricus and D. superans. Specimens whose position was in disagreement with the accepted taxonomy are shown in gray. Sequences of the Biston and Phthonandria genus were used as the outgroup. The coefficients near the tree nodes represent the statistical support for respective branches. The coefficients below 80 are not shown in the picture

Eastern Sayan Mountains) [13]. During the outbreaks, both species could expand their ranges manyfold [31]. Thus, formation of $D$. sibiricus - D. pini hybrids in nature seems not so improbable.

\section{Conclusion}

In the present work we investigated genetic diversity of eight Dendrolimus species in Eurasia by integration of our own data with all that obtained on different genetic markers from different studies. While only supporting some of the appreciated ideas on evolutionary relationships among D. spectabilis, D. punctatus and D. tabulaeformis (SPT cluster), we unraveled the status of D. kilmez as a new species and showed cases of integration of D. sibiricus mitochondrial DNA sequences to European populations of its close relative $D$. pini. Subspecies status of

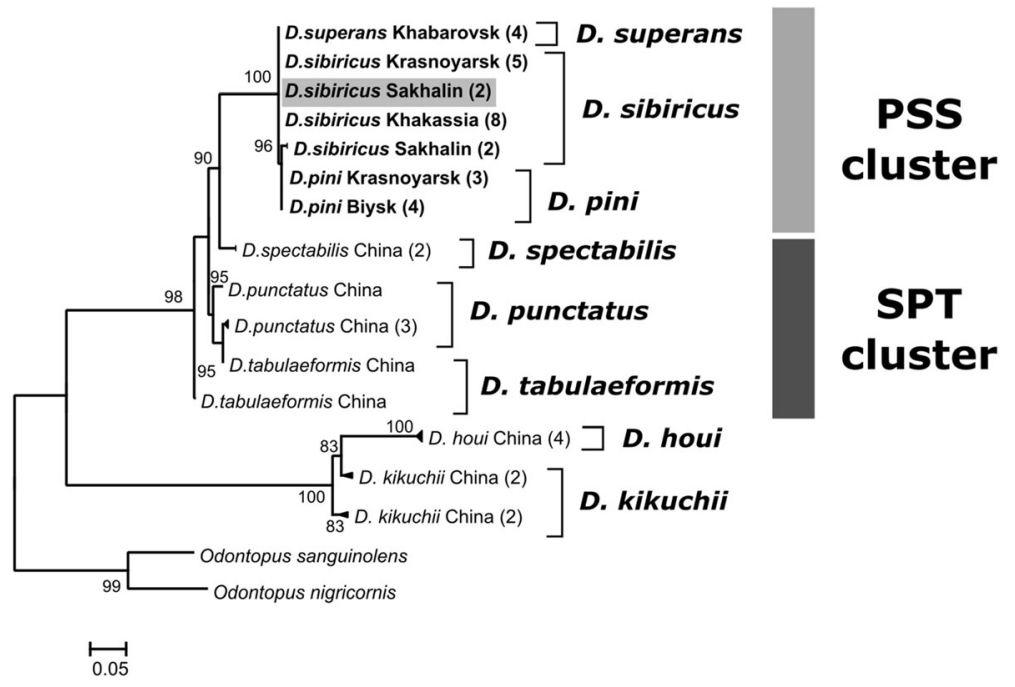

Fig. 5 Phylogeny of Dendrolimus based on a portion of COIl gene. Specimens obtained in the present study are shown in bold. SPT, cluster of closely related species: D. spectabilis, D. punctatus and D. tabulaeformis. PSS, cluster of closely related species: D. pini, D. sibiricus and D. superans. Specimens whose position was in disagreement with the accepted taxonomy are shown in gray. Sequences of the Odontopus genus were used as the outgroup. The coefficients near the tree nodes represent the statistical support for respective branches. The coefficients below 80 are not shown in the picture 
D. tabulaeformis was supported. Almost uniform genetic variability of continental $D$. sibiricus populations was shown, suggesting its impetuous spread to the west of Eurasia. Thereby, our data support appreciation of D. sibiricus as an important pest for Europe and its inclusion into A2 list of pests recommended for regulation as quarantine pests [43].

\section{Additional file}

Additional file 1: Localities, number of collected Dendrolimus

specimens and their Genbank accession numbers. (PDF 257 kb)

\section{Acknowledgements}

Authors would like to thank Yuri Gninenko (Moscow) and Galina Yurchenko (Khabarovsk) for providing moth specimens from Sakhalin and Khabarovsk.

\section{Declarations}

This article has been published as part of BMC Genetics Vol 17 Suppl 3, 2016: Selected articles from BGRS\SB-2016: genetics. The full contents of the supplement are available online at https://bmcgenet.biomedcentral.com/ articles/supplements/volume-17-supplement-3.

\section{Funding}

The work was partially supported by the State scientific project number 0324-2015-0003. Publication of this article has been funded by the author Alexander Blinov.

\section{Availability of data and materials}

The nucleotide sequence from the present work published in the GeneBank under the accession numbers: KJ007736 - KJ007819.

\section{Authors' contributions}

$A B$ and $Y B$ conceived and supervised the whole study; BW, VCM, and $Y B$ collected and identified morphological data; $\mathrm{AK}$ and $\mathrm{KU}$ performed sequencing, conducted analyses; BW, VCM, and VF drafted the manuscript. All authors read and approved the final manuscript.

\section{Competing of interest}

The authors declare that they have no competing of interest.

\section{Consent for publication}

Not applicable.

\section{Ethics approval and consent to participate}

No specific permits were required for the described field studies, the locations are not privately-owned and the field studies did not involve endangered or protected species.

\section{Author details}

Institute of Cytology and Genetics, the Siberian Branch of the Russian Academy of Science, 10 Prospekt Lavrentyeva, Novosibirsk 630090, Russia. 2USDA-APHIS-PPQ CPHST, Otis Laboratory, Building 1398, Otis Air National Guard Base, Buzzards Bay, MA 02542, USA. ${ }^{3}$ Department of Biological Sciences, Marshall University, 1601 5th Avenue, Huntington, WV 25755, USA.

${ }^{4} \mathrm{~V} . \mathrm{N}$. Sukachev Institute of Forest, the Siberian Branch of the Russian

Academy of Science, 50/28 Akademgorodok, Krasnoyarsk 660036, Russia.

\section{Published: 22 December 2016}

\section{References}

1. Fan J, Xie Y, Xue J, Liu R. The effect of Beauveria brongniartii and its secondary metabolites on the detoxification enzymes of the pine caterpillar, Dendrolimus tabulaeformis. J Insect Sci. 2013:13:44.

2. Mikkola K, Ståhls G. Morphological and molecular taxonomy of Dendrolimus sibiricus Chetverikov stat. rev. and allied lappet moths (Lepidoptera: Lasiocampidae), with description of a new species. Entomol Fenn. 2008;19:65-85.
3. Linnaeus C. Systema naturæ per regna tria naturæ, secundum classes, ordines, genera, species, cum characteribus, differentiis, synonymis, locis Tomus I. 1758.

4. Tschetverikov S. Noch einmal uber Dendrolimus pini L., D. segregatus Butl. und D. sibiricus Tshtvr., nom. nov. (laricis Tshtvr.). (Lepidoptera, Lasiocampidae). Rev Russe d'Entomologie. 1908;1:1-7.

5. Walker F, Gray J. List of the specimens of lepidopterous insects in the collection of the British Museum: order of the Trustees. 1855.

6. Hou TQ. The pine caterpillars of China. Beijing: Institute of Zoology, Academia Sinica, Science Press; 1987.

7. Diaz JH. The evolving global epidemiology, syndromic classification, management, and prevention of caterpillar envenoming. Am J Trop Med Hyg. 2005;72:347-57.

8. Sierpiñska A. Towards an Integrated Management of Dendrolimus pini L. In: McManus ML, Liebhold AM, editors. Popul. Dyn. Impacts, Integr. Manag. For. Defoliating Insects. USDA For. Serv. Gen. Tech. Rep. NE-247. 1998. p. 129-42.

9. Rozhkov A. Sibirskiy shelkopryad [Siberian moth]. Izd Akad Nauk SSSR. 1963;175.

10. Gninenko Y, Orlinskii A. Dendrolimus sibiricus in the coniferous forests of European Russia at the beginning of the twenty-first century. EPPO Bull OEPP/EPPO. 2002;32:481-3.

11. Baranchikov Y, Pet'ko V, Ponomarev V. The Russians are coming - aren't they? Siberian moth in European forests. In: Gottschalk K, Fosbroke S, editors. Proceedings, Interag. Res. forum gypsy moth other invasive species. Washington: USDA Forest Service; 2006. p. 18-20.

12. OEPP/EPPO. Dendrolimus sibiricus and Dendrolimus superans. Bull. 35. Bulletin OEPP/EPPO; 2005. p. 390-5.

13. Baranchikov $Y$. Siberian moth - a relentless modifier of taiga forest ecosystems in North-ern Asia. Boreal For. a Chang. World Challenges Needs Actions. Krasnoyarsk: Sukachev Insttue of Forest SB RASc; 2011. p. 105-7.

14. Baranchikov $Y$, Kondakov $Y$. Outbreaks of the Siberian moth Dendrolimus superans sibiricus Tschtvrk in central Siberia. In: Gottschalk K, Fosbroke S, editors. USDA Interag. Gypsy moth Forum. Washington: USDA Forest Service; 1997. p. 10-3.

15. Lajonquiere Y. Lasiocampides orientaux nouveaux ou mal connus et Description du Genre Chonopla nov. Bull Soc ent Fr. 1979;84:184-201.

16. Matsumura S. New species and subspecies of moths from the Japanese Empire. J Coll Agr, Hokkaido Imp Univ Sapporo Japan. 1927;19:1-91.

17. Kong XB, Zhang Z, Zhao CH, Bin WH. Female sex pheromone of the Yunnan pine caterpillar moth Dendrolimus houi: first (E, Z)-isomers in pheromone components of Dendrolimus spp. J Chem Ecol. 2007:33:1316-27.

18. Chai S, Xu G, Xie K, Lu N, Li G. Forecast of Occurrence Stage and Harm Extent of Dendrolimus houi. J Northwest For Coll. 2002:17:54-7.

19. Zhang $\mathrm{S}$, Zhang Z, Wang $\mathrm{H}$, Kong X. Antennal transcriptome analysis and comparison of olfactory genes in two sympatric defoliators, Dendrolimus houi and Dendrolimus kikuchii (Lepidoptera: Lasiocampidae). Insect Biochem Mol Biol. 2014;52C:69-81.

20. Tsai P, Liu Y. Study of the genus Dendrolimus (Lasiocampidae) of China with descriptions of two new species and one new subspecies. Acta Entomol Sin. 1962:11:237-52

21. Butler A. Descriptions of new species of Heterocera from Japan, Part 3, Geometries. Ann Mag Nat Hist. 1878:5:393-419.

22. Zhao Q-S, Wu W-B, Lu G-P, Yuang X, Li S-K, Jiang J-C. Hybridization experiments with two species of Dendrolimus. Acta Entomol Sin. 1992;35:28-32.

23. Zhang A-B, Kong X-B, Li D-M, Liu Y-O. DNA fingerprinting evidence for the phylogenetic relationship of eight species and subspecies of Dendrolimus (Lepidoptera: Lasiocampidae) in China. Acta Entomol Sin. 2004:47:236-42.

24. Reed DH, Frankham R. Correlation between Fitness and Genetic Diversity. Conserv Biol. 2003:17:230-7.

25. Markert JA, Champlin DM, Gutjahr-Gobell R, Grear JS, Kuhn A, McGreevy TJ, et al. Population genetic diversity and fitness in multiple environments. BMC Evol Biol. 2010:10:205.

26. Miko I, LeJeune L, editors. Essentials of Genetics. Cambridge: NPG Education; 2009.

27. Chen F, Shi J, Luo Y-Q, Sun S-Y, Pu M. Genetic characterization of the gypsy moth from China (Lepidoptera, Lymantriidae) using inter simple sequence repeats markers. Hajibabaei M, editor. PLoS One. 2013;8:e73017. Public Library of Science.

28. Agnarsson I, Avilés L, Maddison WP. Loss of genetic variability in social spiders: genetic and phylogenetic consequences of population subdivision and inbreeding. J Evol Biol. 2013;26:27-37. 
29. Dai Q-Y, Gao Q, Wu C-S, Chesters D, Zhu C-D, Zhang A-B. Phylogenetic reconstruction and DNA barcoding for closely related pine moth species (Dendrolimus) in China with multiple gene markers. PLoS One. 2012;7:e32544.

30. Jia YD, Kong XB, Zhang Z, Wang HB, Wang FY, Zhang S. Taxonomic position of four species of pine caterpillar moths based on sequences analysis of $\mathrm{CO}$ gene. J Northeast For Univ. 2011;39:1-5.

31. USDA. Dendrolimus Pine Moths. In: Hardin JA, Suazo A, editors. New Pest Response Guidel. 1st ed. Washington: USDA-APHIS-PPQ-CPHST; 2011. p. 200.

32. Vavilova V, Sormacheva I, Woyciechowski M, Eremeeva N, Fet V, Strachecka A, et al. Distribution and diversity of Nosema bombi (Microsporidia: Nosematidae) in the natural populations of bumblebees (Bombus spp.) from West Siberia. Parasitol Res. 2015;3373-83.

33. Qin J, Zhang Y, Zhou X, Kong X, Wei S, Ward RD, et al. Mitochondrial phylogenomics and genetic relationships of closely related pine moth (Lasiocampidae: Dendrolimus) species in China, using whole mitochondrial genomes. BMC Genomics. 2015;16:428.

34. Okonechnikov K, Golosova O, Fursov M. Unipro UGENE: a unified bioinformatics toolkit. Bioinformatics. 2012;28:1166-7.

35. Guindon S, Dufayard J-F, Lefort V, Anisimova M, Hordijk W, Gascuel O. New algorithms and methods to estimate maximum-likelihood phylogenies: assessing the performance of PhyML 3.0. Syst. Biol. 2010;59:307-21.

36. Baojia G, Ziyan N, Lijie G. Genetic Diversity and Population Differentiation of Main Species of Dendrolimus (Lepidoptera) in China and Influence of Environmental Factors on Them. In: Grillo O, Venora G, editors. Dyn. Process. Biodivers. - Case Stud. Evol. Spat. Distrib. Rijeka: InTech. 2011. p. 321-46.

37. Craft KJ, Pauls SU, Darrow K, Miller SE, Hebert PDN, Helgen LE, et al. Population genetics of ecological communities with DNA barcodes: an example from New Guinea Lepidoptera. Proc Natl Acad Sci U S A. 2010;107:5041-6.

38. Jiang X-F, Cao W-J, Zhang L, Luo L-Z. Beet webworm (Lepidoptera: Pyralidae) migration in China: evidence from genetic markers. Environ Entomol. 2010:39:232-42.

39. Lajonquiere Y. Genres Dendrolimus Germar, Hoenimnema n. gen. Cyclophragma Turner. 10e Contrib. a l'etude des Lasiocampides. Paris: Annales de la Société Entomologique de France; 1973. p. 509-92.

40. Rozhkov A. Derevo i nasekomoye [Tree and an Insect]. Nauka; 1981. p. 192.

41. Ranjan SK, Mallick CB, Saha D, Vidyarthi AS, Ramani R. Genetic variation among species, races, forms and inbred lines of lac insects belonging to the genus Kerria (Homoptera, Tachardiidae). Genet Mol Biol. 2011;34:511-9.

42. Ruiz EA, Rinehart JE, Hayes $J \mathrm{~L}$, Zúñiga G. Effect of geographic isolation on genetic differentiation in Dendroctonus pseudotsugae (Coleoptera: Curculionidae). Hereditas. 2009;146:79-92.

43. EPPO. EPPO A1 and A2 Lists of Pests Recommended for Regulation as Quarantine Pests. EPPO Bull. 2008.

44. Folmer O, Black M, Hoeh W, Lutz R, Vrijenhoek R. DNA primers for amplification of mitochondrial cytochrome c oxidase subunit I from diverse metazoan invertebrates. Mol Mar Biol Biotechnol. 1994;3:294-9.

45. Bugrov AG, Novikova OS, Netesova ES, Gorochov AV, Blinov AG. Using DNA sequences of two mitochondrial genes (COI and COII) for taxonomy and phylogeny of Bradyporinae katydids (Orthoptera, Ensifera, Tettigoniidae). Euroasian Entomol J. 2009:8:1-8.

46. Pasiecznik NM, Smith IM, Watson GW, Brunt AA, Ritchie B, Charles LMF. CABI/EPPO distribution maps of plant pests and plant diseases and their important role in plant quarantine. Nat Hist. 2005;1-7.

\section{Submit your next manuscript to BioMed Central and we will help you at every step:}

- We accept pre-submission inquiries

- Our selector tool helps you to find the most relevant journal

- We provide round the clock customer support

- Convenient online submission

- Thorough peer review

- Inclusion in PubMed and all major indexing services

- Maximum visibility for your research

Submit your manuscript at www.biomedcentral.com/submit
Biomed Central 